\title{
Collagen Fiber Autofluorescence Level in Evaluating the Biological Properties of Tissue Grafts
}

\author{
DOI: $10.17691 / \mathrm{stm} 2017.9 .2 .10$ \\ Received August 22, 2016
}

M.S. Makarov, PhD, Researcher, Laboratory of Cell Transplantation and Immunotyping;

M.V. Storozheva, Junior Researcher, Laboratory of Cell Transplantation and Immunotyping;

N.V. Borovkova, MD, DSc, Head of Laboratory of Cell Transplantation and Immunotyping

N.V. Sklifosovsky Research Institute of Emergency Care, 3 Bolshaya Sukharevskaya Square, Moscow, 129010,

Russian Federation

The aim of the investigation was to study the possibilities of evaluating the biological properties of various tissue grafts analyzing autofluorescence level of their collagen fibers.

Materials and Methods. The study involved various types of standard-produced tissue grafts, some of them being exposed to additional treatment to stimulate changes in collagen fiber structure. Analysis of preparations was made using light, fluorescent and confocal microscopy. To evaluate human cell adhesion on tissue grafts with different autofluorescence levels, M-22 human fibroblasts and human blood platelets were used.

Results. Collagen autofluorescence has been registered in both fixed and non-fixed tissue graft samples, autofluorescence level of single fibers reflecting the extent of their compaction. Damage to the initial collagen structure leads to changes in tissue graft composition due to formation of picrinophilic fibers with very high autofluorescence levels, which do not appear in normal tissues or after collagen decondensation in conditions of hypotonia. Grafts with collagen fiber autofluorescence intensity $\leqslant 30$ foot-candles are highly adhesive for M-22 human fibroblasts and donor platelets, whereas grafts with autofluorescence levels of more than 40 foot-candles exhibit significantly lower adhesive properties.

Conclusion. Collagen autofluorescence analysis provides important data about connective tissue topography, intercellular matrix integrity and allows collagen defects to be revealed, even in non-fixed tissue slices and grafts.

Key words: tissue grafts; collagen autofluorescence; cell adhesion.

Allogeneic grafts are increasingly used in reconstructive and reparative surgery. The sources of these grafts are the trabecular bone and the cortical bone, serous membranes (pericardium, peritoneum, pleura), dura mater, skin, blood vessels [1-3]. At present, tissue allografts are actively applied in traumatology to replace bone loss and in burn injury medicine as wound coverings, they also serve as fixing anti-adhesive implants in surgery to perform hernioplasty [2-5]. The use of human tissues as a natural matrix in production of combined grafts is a promising trend [6-8].

In recognition of a wide range of tissue graft applications, special attention should be paid to their quality. As a rule, the process of tissue graft manufacturing involves donor tissue harvesting, its modification, sterilization and storage. Notably, at every stage mentioned above, alteration or even damage to the collagen matrix structure may occur. Structural integrity of the graft can be evaluated by analyzing its biomechanical properties, such as stability, resilience, tensile strength $[9,10]$. However, evaluation of tissue graft quality is mostly performed by means of light microscopy using standard histological and, less often, histochemical methods [2, 6, 11-13]. When a graft undergoes histological examination, particular attention is paid to the analysis of the arrangement of intercellular matrix components, first of all, collagen fibers, with no due regard for such phenomenon as autofluorescence.

For contacts: Maksim S. Makarov, e-mail: mcsimmc@yandex.ru 
Autofluorescence ability (the natural fluorescence displayed by tissue when exposed to exciting light without specific fluorochrome dyes) is a remarkable collagen property $[14,15]$ determined by its specific amino acid composition, three-dimensional organization of whole molecules as well as molecule complexes (complete collagen fibrils or fibers). Therefore, it is fair to suppose that collagen autofluorescence analysis will provide the possibility to evaluate the inner topography of tissue grafts on both standard histological preparations and non-fixed transplants.

The aim of the investigation was to study the possibilities of evaluating the biological properties of various tissue grafts analyzing autofluorescence level of their collagen fibers.

Materials and Methods. Collagen autofluorescence analysis was performed both on histological slices and whole graft samples. Tissue grafts were studied on the basis of dermal matrix (15 various samples), pericardium (5 samples), peritoneum (4 samples), dura mater (4 samples), the cortical bone (4 samples) manufactured using standard techniques [3, 4, 16, 17], and also tissue donor skin and aorta samples (5 samples of each tissue), liquid type I collagen from human tendon and tendon-based collagen bands (10 samples). Besides, collagen fiber autofluorescence was studied on grafts exposed to additional influences inducing structural changes of collagen. For this purpose, the following histological preparations were analyzed: native tissue donor skin (control), tissue donor skin after $4 \mathrm{~h}$ incubation in distilled water (severe hypotonia), tissue donor skin after 14 days of storage in culture medium for DMEM cells at $37^{\circ} \mathrm{C}$, dermal matrix [16], dermal matrix sutured subcutaneously in laboratory mice after 28 days of experiment. All transplants were produced in tissue conservation department of N.V. Sklifosovsky Research Institute of Emergency Care. Histological preparations were examined using light and fluorescence microscopy, whole graft samples were studied by means of fluorescence and confocal microscopy. Histological slices were stained with hematoxylin and eosin and van Gieson stain.

To evaluate adhesion of human cells on tissue grafts with different mean collagen fluorescence intensity $\left(\mathrm{MFI}_{\text {col }}\right), \mathrm{M}-22$ human fibroblasts and human blood platelets were used. M-22 human fibroblasts were cultured for $3-5$ days at $37^{\circ} \mathrm{C}$ and $5 \% \mathrm{CO}_{2}$ in DMEM medium with $10 \%$ fetal bovine serum (Gibco, USA) in 6-well cell culture plates (Costar, Corning, USA) containing graft samples. Platelet concentrates obtained from blood donors by automated apheresis were used as sources of human blood platelets, their total number in a sample containing no less than $50 \%$ of platelets with granules (structurally and functionally complete platelets). The content of platelets with granules was assessed by our original method based on vital platelet staining [17]. To assess platelet adhesion on tissue grafts, Petri dishes with $2 \mathrm{ml}$ of platelet concentrate and graft samples were incubated for $0.5-1 \mathrm{~h}$ at $37^{\circ} \mathrm{C}$. To reveal adhered M-22 fibroblasts and platelets, there were used methods developed by the authors and based on staining the cells with vital fluorochrome dyes [17, 18] with their subsequent analysis under fluorescence microscope.

Confocal microscope Nikon Eclipse 80i in combination with fluorescent lamp Nikon Intesilight C-HGFi (Nikon Corporation, Japan) was employed.

Collagen autofluorescence in non-fixed tissues was registered using blue filter ( $\lambda_{\text {excitation: }}$ : $380-420 \mathrm{~nm}$, $\lambda_{\text {emission}}$ : from $450 \mathrm{~nm}$, exposure time: $1 \mathrm{~s}$ ), histological preparations were studied with red filter ( $\lambda_{\text {excitation}}: 510$ $560 \mathrm{~nm}, \lambda_{\text {emission: }}$ : from $575 \mathrm{~nm}$, exposure time: $1 \mathrm{~s}$ ).

Quantitative analysis of collagen autofluorescence was performed using $\mathrm{MFI}_{\text {col }}$ parameter determined by the same method as the one applied for fluorescence analysis of vitally stained cells [18]. The obtained digital photos were exported to Adobe Photoshop 8 software application to select separate images of collagen fibers and determine their autofluorescence level in footcandles.

The obtained statistical data were processed using analysis of variance in Microsoft Excel 2000 software. The mean $(\mathrm{M})$ and mean square deviations $(\sigma)$ were calculated.

\section{Results and Discussion}

Autofluorescence analysis of collagen grafts. Collagen autofluorescence was registered both on whole graft samples and histological slices, which made it possible to visualize the boundaries of collagen fibers, their thickness and orientation. Separate fibrils and fibers of various diameters were observed in the example of type I collagen gel derived from cadaver tendon (Figure 1), with thicker bundles of collagen fibrils

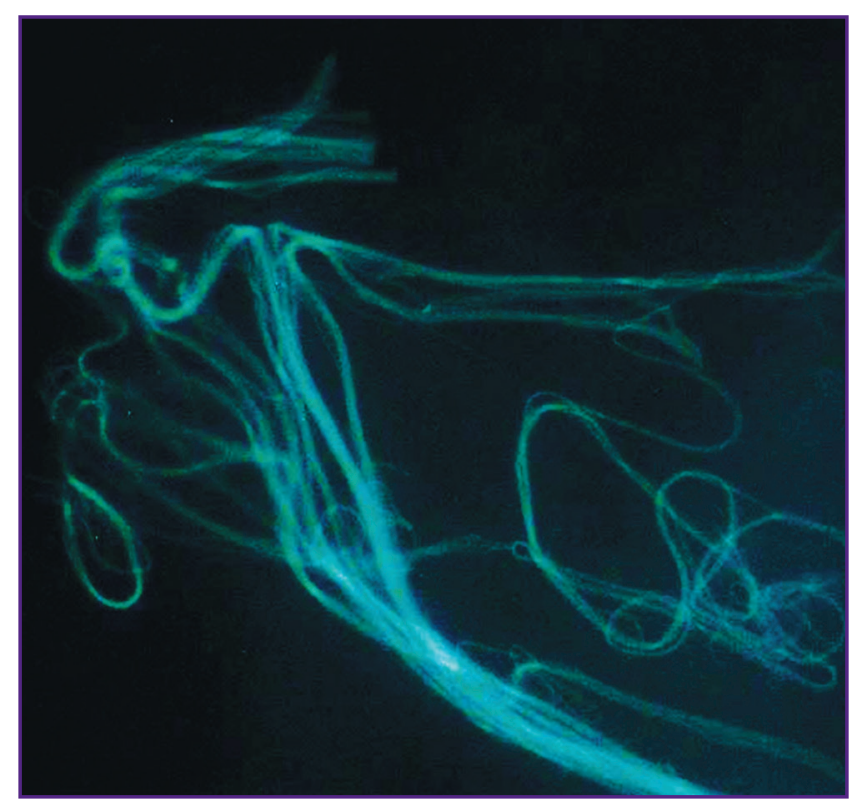

Figure 1. Autofluorescence of selected type I collagen fibers derived from tissue donor tendon; $\times 400$ 
Adhesive properties of tissue grafts based on autofluorescence level of collagen fibers

\begin{tabular}{|c|c|c|c|}
\hline $\begin{array}{l}\text { Types of collagen- } \\
\text { containing grafts }\end{array}$ & $\begin{array}{l}\text { Autofluorescence level } \\
\text { of collagen fibers } \\
\text { (foot-candles) } \\
\text { [M } \pm \sigma \text { (min-max)] }\end{array}$ & $\begin{array}{l}\text { Adhesive activity } \\
\text { of human diploid cells } \\
\text { (M-22 fibroblasts) }\end{array}$ & $\begin{array}{l}\text { Adhesive activity } \\
\text { of human platelets }\end{array}$ \\
\hline Collagen bands & $20.5 \pm 0.5(15-24)$ & \multirow{2}{*}{$\begin{array}{l}\text { Form a confluent or subconfluent } \\
\text { monolayer, proliferate actively }\end{array}$} & \multirow{2}{*}{$\begin{array}{l}\text { Form large aggregates } \\
\text { (up to } 100 \mu \mathrm{m} \text { in diameter }\end{array}$} \\
\hline Dermal matrix & $28.0 \pm 0.6(25-30)$ & & \\
\hline Tissue donor skin & $37.5 \pm 0.7(33-40)$ & \multirow{2}{*}{$\begin{array}{l}\text { Adhere diffusely (without } \\
\text { contacting with other cells) } \\
\text { or form small aggregates }\end{array}$} & \multirow{2}{*}{$\begin{array}{l}\text { Form small/medium-sized } \\
\text { aggregates or adhere } \\
\text { diffusely }\end{array}$} \\
\hline Aorta & $35.0 \pm 0.3(33-38)$ & & \\
\hline Pericardium & $45.5 \pm 1.9(41-50)$ & \multirow{4}{*}{ Adhere single cells (per $1 \mathrm{~mm}^{2}$ ) } & \multirow{4}{*}{ Do not adhere } \\
\hline Peritoneum & $47.0 \pm 1.1(44-51)$ & & \\
\hline Dura mater & $57.5 \pm 2.5(50-70)$ & & \\
\hline Cortical bone & $80.0 \pm 2.2(50-90)$ & & \\
\hline
\end{tabular}

having a higher autofluorescence level. $\mathrm{MFI}_{\mathrm{col}}$ value of separate fibrils varied from 8 to 15 foot-candles, that of whole collagen fibers - from 20 to 25 foot-candles, the fibrils hardly contacted with each other. In collagen bands, almost all collagen was grouped in fibers whose $\mathrm{MFI}_{\text {col }}$ level also amounted to 20-25 footcandles, i.e. it can be stated that collagen compaction occurred during lyophilization of collagen bands. In tissue grafts, $\mathrm{MFI}_{\text {col }}$ value tended to be higher than 25 footcandles (See the Table), reaching the highest value in dura mater and cortical bone grafts containing very dense and thick fibers. Thus, $\mathrm{MFI}_{\text {col }}$ parameter provides the possibility to evaluate the extent of collagen fiber compaction in various tissue grafts.

On the other hand, collagen compaction level of the original tissue can be changed by subsequent actions in the process of graft manufacturing. The use of tissue grafts both in clinical practice and tissue engineering often implies that grafts are exposed to certain factors able to influence their structure and collagen fiber topography. Currently, the procedure of graft devitalization (removing cellular components out of their composition) is often applied [3-6]. Production of devitalized
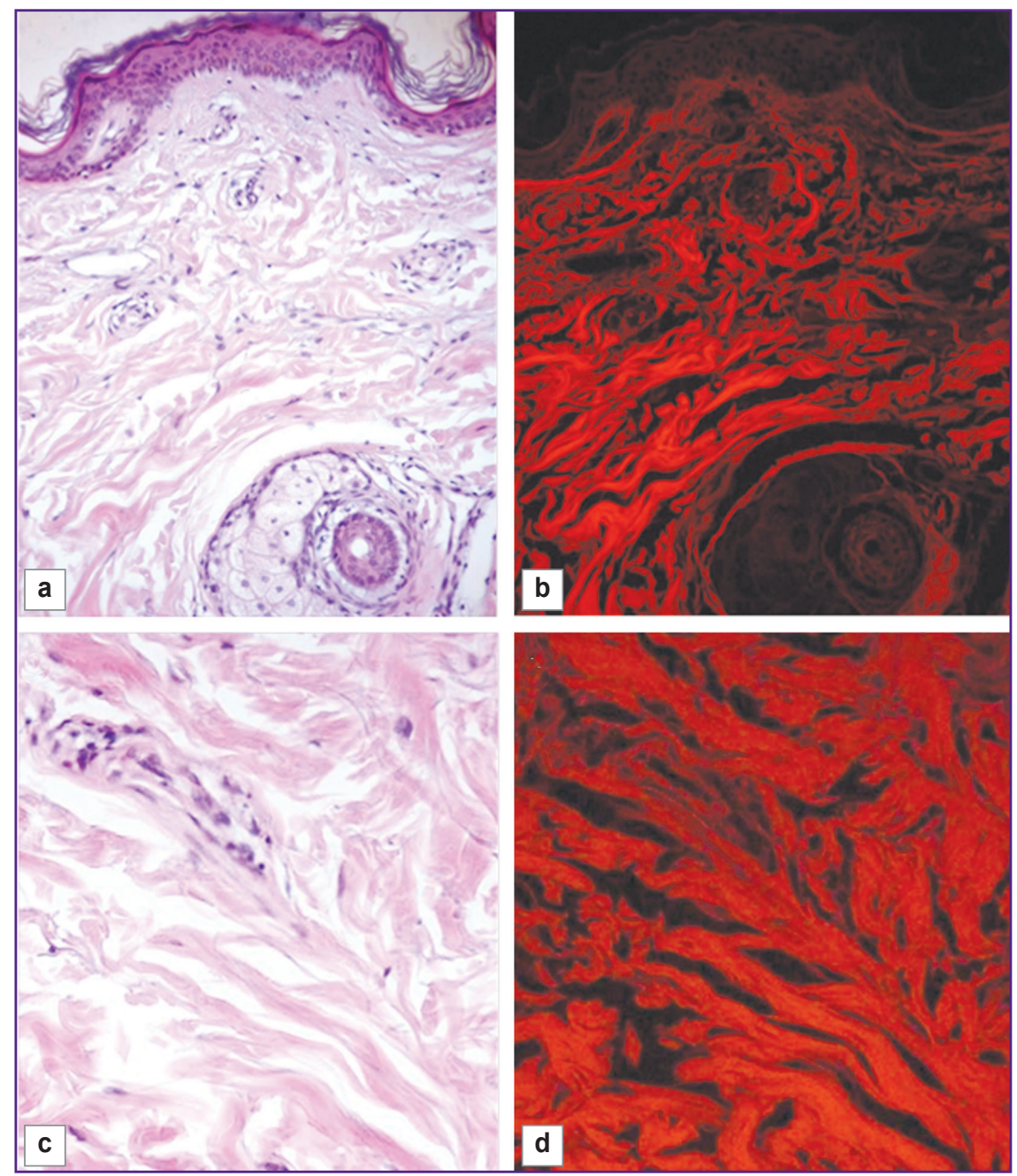

Figure 2. Native donor skin:

(a), (c) hematoxylin and eosin staining; (b), (d) autofluorescence of collagen fibers; $\times 100$ (top row) and $\times 400$ (bottom row) 
collagen matrices is based on the use of detergents, solutions with high ionic strength and other chemically active substances, potentially able to damage the original collagen structure and its topography.

In the present work, devitalization effects were studied on histological preparations of dermal matrix using original native tissue donor skin preparations as control. It was established that graft fixation did not influence $\mathrm{MFI}_{\text {col }}$ level significantly in the original skin: it was possible to observe collagen autofluorescence clearly in histological preparations throughout the section area (Figure 2), with the highest fluorescence intensity noticed in the largest fibers (35-40 foot-candles). At the same time, weak residual fluorescence of cell cytoplasm was registered, which may be attributed to the effects of formalin fixation enhancing fluorescence. Dermal matrix preparations showed a decrease in autofluorescence of most fibers (up to 28 foot-candles), though no visible structural changes of collagen were observed in transmitted light (Figure 3 (a)). Additionally, there could be revealed the fragments of very bright fibers with $\mathrm{MFI}_{\mathrm{col}}$ level higher than 60 foot-candles (Figure 3 (b), (d)), though such fibers had standard color when stained

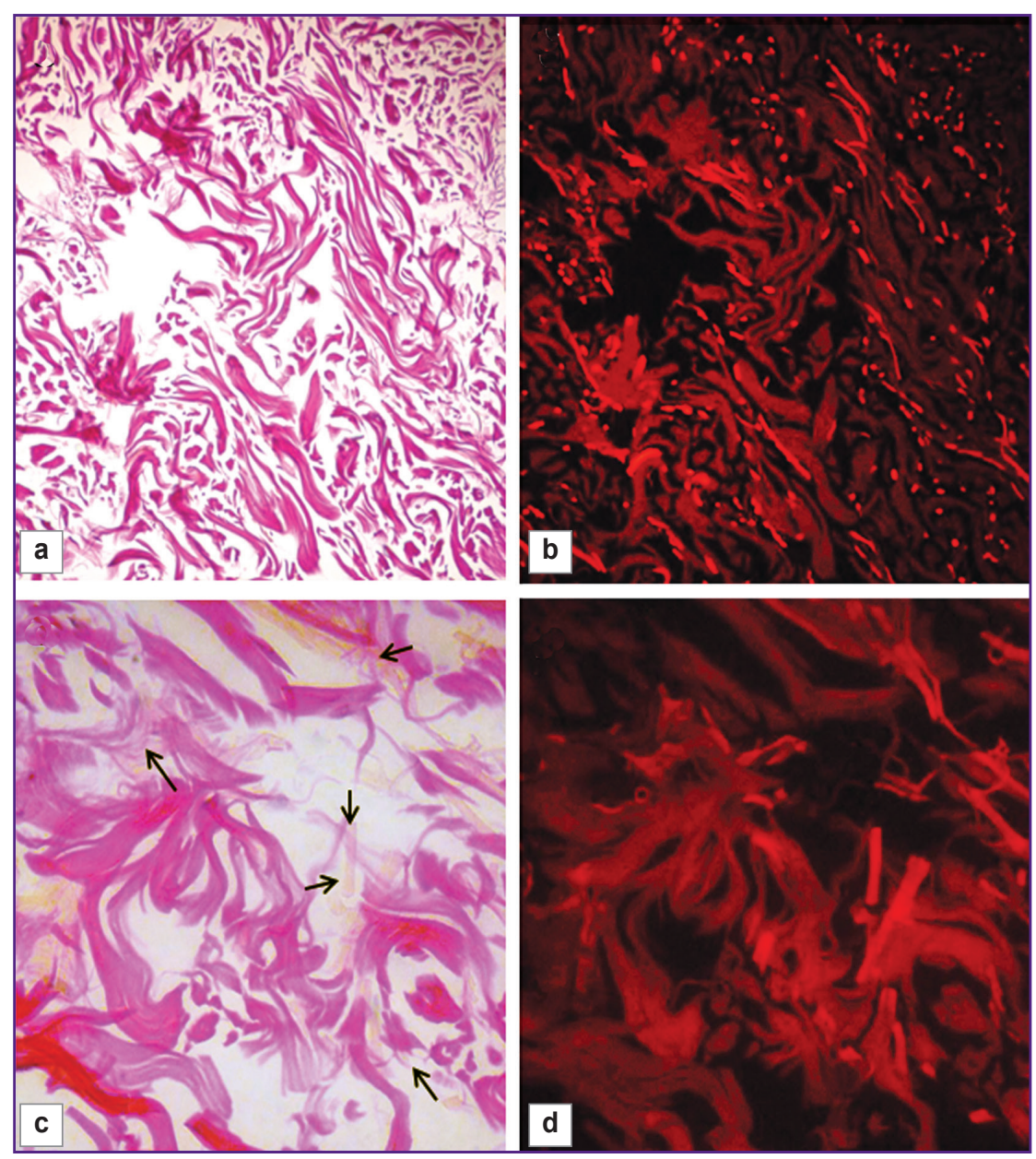

Figure 3. Dermal matrix obtained from tissue donor skin:

(a), (c) van Gieson staining; (b), (d) autofluorescence of collagen fibers; $\times 100$ (top row) and $\times 400$ (bottom row); arrows indicate picrinophilic fibers with hematoxylin and eosin, i.e. autofluorescence intensity was not associated with fiber compaction. On van Gieson staining, the fibers with $\mathrm{MFI}_{\mathrm{col}} \geqslant 60$ footcandles had no typical red color, but were pale-yellow or pale-orange (Figure 3 (c)), i.e. they were picrinophilic (adsorbing picrin, the yellow colorant component), which never occurred in native skin preparations (See Figure 2).

In cell biology, fiber picrinophilia is considered to be an obvious sign of collagen degeneration and its original structure impairment [19], i.e. a portion of collagen fibers is irreversibly destroyed in the process of dermal matrix production. Notably, when collagen autofluorescence is stimulated, picrinophilic fibers are visualized much better under fluorescence microscope than in transmitted light, even with van Gieson staining. This suggests that autofluorescence analysis provides the possibility to reveal severely damaged fibers in graft composition, whose $\mathrm{MFI}_{\text {col }}$ level is normally no higher than 60 footcandles. It should be noted that picrinophilic fibers were almost always present in dermal matrix samples, though their quantity per volume unit varied significantly. It can be concluded that the technology of skin devitalization used in our work does not impair the overall topography of collagen in skin composition, however, it is likely to cause destruction of separate fibers as well as their partial decondensation.

The influence of additional treatment on autofluorescence level of collagen grafts. It was established on the example of type I collagen gel that the selected collagen fibrils do not contain the structures with $\mathrm{MFI}_{\mathrm{col}} \geqslant 60$ foot-candles. Further investigations showed that incubation of whole grafts in conditions of severe hypotonia led to no picrinophilic fibers forming in them either. For example, after incubation of donor skin samples in distilled water, no fibers with $\mathrm{MFI}_{\mathrm{col}} \geqslant 60$ foot-candles were revealed. On the contrary, autofluorescence level was reduced to 15 foot-candles (Figure 4 (a)), i.e. decondensation of collagen bundles without chemical degradation of collagen occurred in that case. On the other hand, fibers with $\mathrm{MFI}_{\text {col }} \geqslant 60$ footcandles were revealed throughout the derma layer of skin flaps after lengthy storage at $37^{\circ} \mathrm{C}$ (Figure 4 (b)), which spoke of complete chemical destruction of derma collagen. That could be caused by the activity of many proteolytic enzymes secreted by cells decomposing during storage. 
Collagen fiber lysis was particularly clearly visualized when studying dermal matrix samples sutured subcutaneously in mice. After 28 days of investigation, the majority of animals exhibited intense infiltration of dermal matrix by inflammatory cells throughout the graft volume (Figure $5(\mathrm{a})$ ), with all fibers in the graft composition having $\mathrm{MFI}_{\text {col }}$ from 60 to 90 foot-candles (Figure 5 (b)), which suggested total collagen degradation. However, such picture was not observed in all the mice. Some of them showed low infiltration of dermal matrix by inflammatory cells (Figure 5 (c)) and, consistently, the number of fibers with $\mathrm{MFI}_{\text {col }} \geqslant 60$ foot-candles was significantly lower and in certain cases it did not exceed their initial level in the graft (Figure 5 (d)). This speaks of the existing potential possibility for allogeneic and xenogenic dermal matrix to survive. Nevertheless, it still remains unclear whether the level of picrinophilic fibers in the original graft affects its ultimate survival in vivo. This problem has yet to be further investigated.

Cell adhesion activity on collagen grafts with different autofluorescence levels. Evaluation of graft biocompatibility with normal cells and tissues is of paramount importance, irrespective of whether the objective of complete tissue graft survival is set or not. First of all, this implies the absence of toxic effect on cultured human diploid cells [6, 10, 11, 20]. Besides, an important property of tissue grafts is their adhesive capabilities. Depending on the set objectives, requirements to graft adhesion can vary. For example, collagen matrix used as base material in tissue engineering and production of combined biografts must be highly adhesive for cells. By contrast, in surgical interventions like hernioplasty, tissue grafts must exhibit anti-adhesive properties. Studying human diploid cell line (M-22 fibroblasts) and platelets, we have found that collagen matrix adhesion depends on the compaction density of collagen (See the Table). Tissue grafts with $\mathrm{MFI}_{\mathrm{col}} \leqslant 30$ foot-candles have the most pronounced adhesive properties, i.e. precisely these collagen grafts are the most suitable for being used as matrix in production of biotransplants. Transplant adhesiveness declines

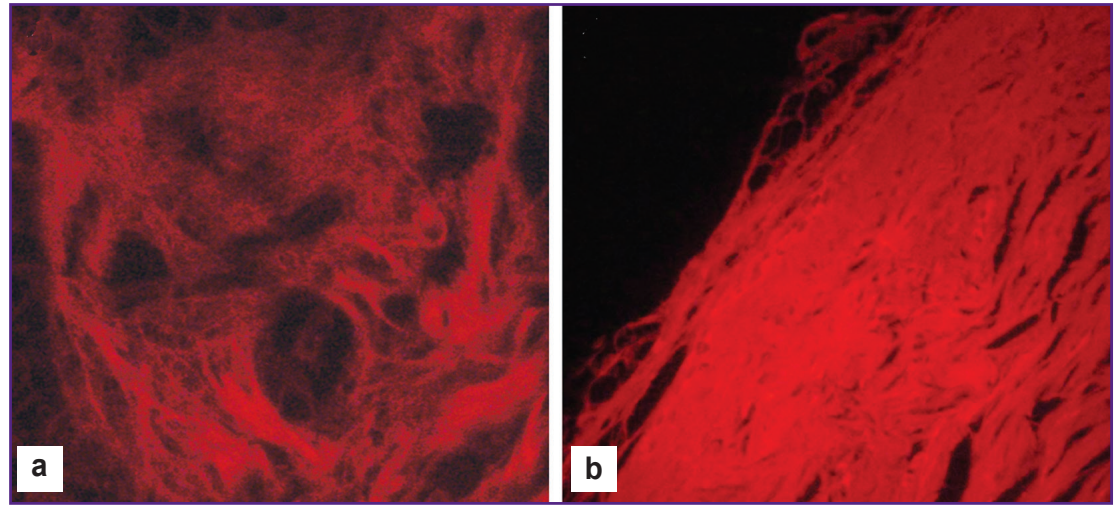

Figure 4. Donor skin samples:

(a) in conditions of hypotonia; (b) after lengthy storage at $37^{\circ} \mathrm{C}$. Autofluorescence of collagen fibers; $\times 400$
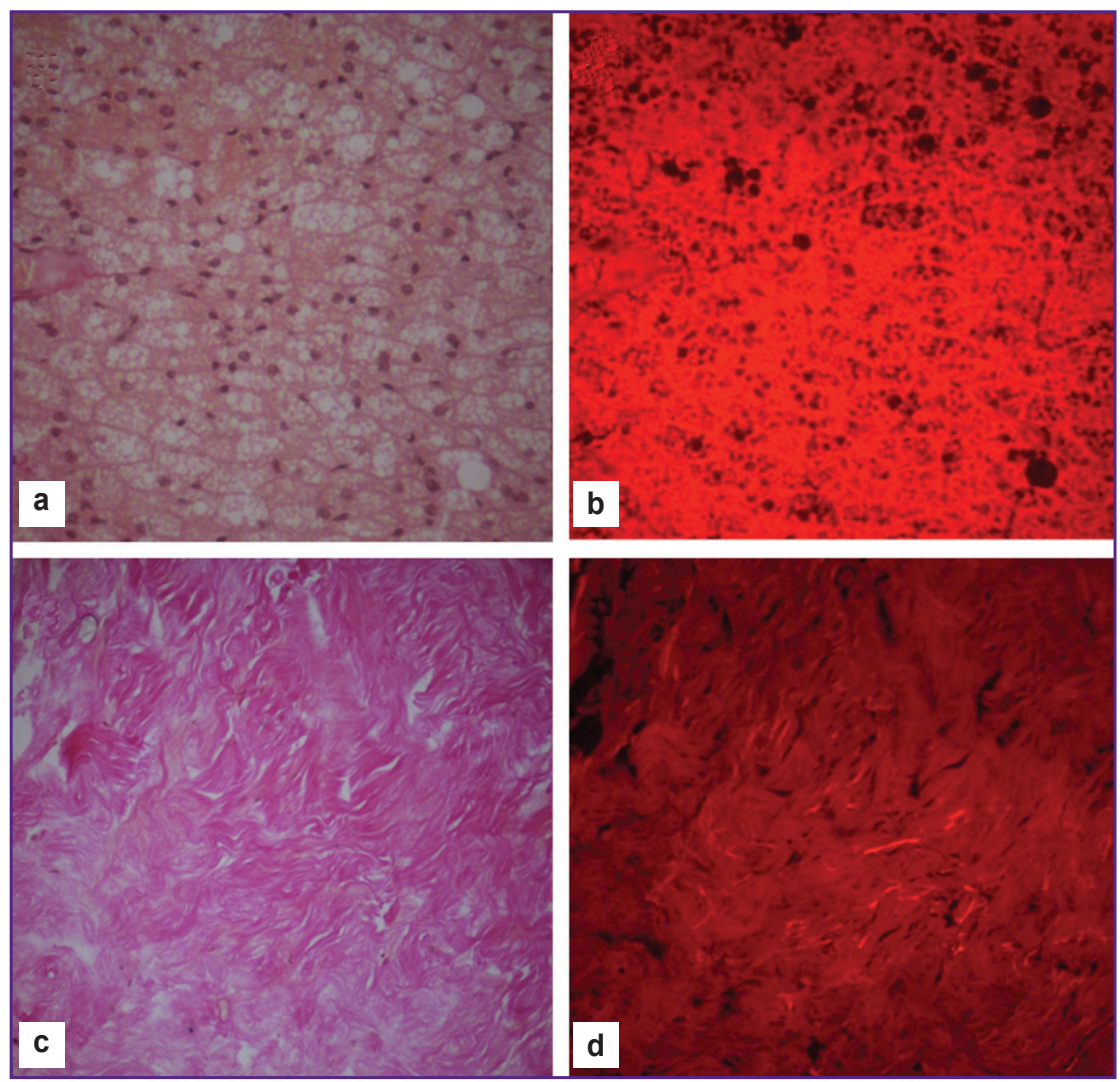

Figure 5. Dermal matrix sutured subcutaneously in laboratory mice after 28 days of experiment: (a), (b) high and (c), (d) low level of infiltration by inflammatory cells: on the left -
van Gieson staining, on the right - autofluorescence of collagen fibers; $\times 100$

sharply at $\mathrm{MFI}_{\text {col }}$ equal to 40 foot-candles and more: fibroblast adhesion on such grafts was weak and there was no platelet adhesion at all. Neither of these types of cells were found in vitro on dura mater graft samples which are currently considered rather challenging for laparoscopic hernioplasty and abdominoplasty in management of ventral hernias [1]. At the same time, there is evidence that dura mater-based grafts can be colonized in vitro by human chondroblasts [5], i.e. 
dura mater has no anti-adhesive properties in relation to chondroblasts. Thus, when evaluating tissue graft biocompatibility with the help of cell cultures, it is necessary among other things to take into consideration the type of cells used.

Conclusion. Autofluorescence analysis offers the possibility not only to reveal collagen fibers in connective tissue composition, but also to evaluate their integrity and compaction. Without specific fluorochrome staining, collagen autofluorescence registration can provide important data about connective tissue topography and intercellular matrix integrity and allow evaluation of collagen defects even in non-fixed tissues and grafts. This enables dynamic analysis of collagen structure when working with cell cultures in vitro, developing and manufacturing new types of combined biografts.

Study Funding. The work was not supported by any financial sources.

Conflicts of Interest. The authors declare no conflicts of interest.

\section{References}

1. Yermolov A., Macedonian T., Radygina M., Yartsev P., Titov G., Petukhov M., Papanino A., Kislitsina O., Andreyev Yu. Evaluation of the possibility of using tissue grafts in abdominal surgery. Khirurg 2015; 2: 47-60.

2. Karmadonov A.V., Podolughny V.I., Zaicov I.N. Using modified xenopericardium in "non-strained plasties" of inferior abdominal wall hernia. Sibirskiy meditsinskiy zhurnal (Tomsk) 2008; 23(2): 28-32.

3. Aleksandrov V.N., Khubulava G.G., Levanovich V.V. Tissue-engineered vascular grafts. Pediatr 2015; 6(1): 87-95.

4. Khvatov V.B., Svishchev A.V., Vaza A.Yu., Borovkova N.V., Mironov A.S., Pokhitonov D.Yu., Andreev Yu.V. Method of manufacturing a lyophilized allograft bone. Transplantologiya 2016; 1: 13-18.

5. Schug-Pass C., Sommerer F., Tannapfel A., Lippert H., Köckerling $F$. The use of composite meshes in laparoscopic repair of abdominal wall hernias: are there differences in biocompatibily? Surg Endosc 2008; 23(3): 487-495, https://doi. org/10.1007/s00464-008-0085-8.

6. Bobrova M.M., Safonova L.A., Agapova O.I., Krasheninnikov M.E., Shagidulin M.Yu., Agapov I.I. Liver tissue decellularization as a promising porous scaffold processing technology for tissue engineering and regenerative medicine. Sovremennye tehnologii v medicine 2015; 7(4): 6-13, https:// doi.org/10.17691/stm2015.7.4.01.

7. Pokhitonov D.Y, Borovkova N.V., Filippov O.P., Klyukvin 1.Y. Khvatov V.B., Ponomaryov I.N., Shugai S.V., Andreev Y.V., Smirnov S.V., Zhirkova E.A. Experimental substantiation and clinical use of a combination of dermal matrix with allogenic or autologous cells for the treatment of extensive traumatic wounds. Bull Exp Biol Med 2014; 157(5): 705-710, https://doi.org/10.1007/s10517-014-2647-1.
8. Monteiro G.A., Rodriguez N.L., Delossantos A.I., Wagner C.T. Short-term in vivo biological and mechanical remodeling of porcine acellular dermal matrices. J Tissue Eng 2013; 4: 204173141349018, https://doi.org/10.1177/ 2041731413490182.

9. Lamme E.N., de Vries H.J., van Veen H., Gabbiani G., Westerhof W., Middelkoop E. Extracellular matrix characterization during healing of full-thickness wounds treated with a collagen/elastin dermal substitute shows improved skin regeneration in pigs. J Histochem Cytochem 1996; 44(11): 1311-1322, https://doi.org/10.1177/44.11.8918906.

10. Ahlfors J.-E.W., Billiar K.L. Biomechanical and biochemical characteristics of a human fibroblast-produced and remodeled matrix. Biomaterials 2007; 28(13): 2183-2191, https://doi.org/10.1016/j.biomaterials.2006.12.030.

11. Jiang H., Rhee S., Ho C.-H., Grinnell F. Distinguishing fibroblast promigratory and procontractile growth factor environments in 3-D collagen matrices. FASEB J 2008; 22(7): 2151-2160, https://doi.org/10.1096/fj.07-097014.

12. Pedersen J.A., Boschetti F., Swartz M.A. Effects of extracellular fiber architecture on cell membrane shear stress in a 3D fibrous matrix. J Biomech 2007; 40(7): 1484-1492, https://doi.org/10.1016/j.jbiomech.2006.06.023.

13. Richards-Kortum R., Sevick-Muraca E. Quantitative optical spectroscopy for tissue diagnosis. Annu Rev Phys Chem 1996; 47(1): 555-606, https://doi.org/10.1146/annurev. physchem.47.1.555.

14. Monici M. Cell and tissue autofluorescence research and diagnostic applications. Biotechnol Annu Rev 2005; 227256, https://doi.org/10.1016/s1387-2656(05)11007-2.

15. Baschong W., Suetterlin R., Laeng R.H. Control of autofluorescence of archival formaldehyde-fixed, paraffinembedded tissue in confocal laser scanning microscopy (CLSM). J Histochem Cytochem 2001; 49(12): 1565-1571, https://doi.org/10.1177/002215540104901210.

16. Khubutija M.Sh., Andreev J.V., Borovkova N.V., Khvatov V.B., Mironov A.S., Zhirkova E.A., Ponomarev I.N., Volkov K.S., Shugaj S.V., Konjushko O.I., Makarov M.S. Sposob izgotovleniya dermal'nogo matriksa [Method for making dermal matrix]. Patent RU 2524619. 2014.

17. Makarov M.S., Khvatov V.B., Konjushko O.I., Borovkova N.V., Storozheva M.V., Ponomarev I.N. Metod morfofunktsional'noy otsenki kletochnogo komponenta biotransplantatov [Method for morphofunctional assessment of cell component of biografts]. Patent RU 2484472. 2013.

18. Makarov M.S., Kobzeva E.N., Vysochin I.V., Borovkova N.V., Khvatov V.T. Morphofunctional analysis of human platelets by vital staining. Bull Exp Biol Med 2014; 156(3): 409-412, https://doi.org/10.1007/s10517-014-2360-0.

19. Roskin G.I., Levinson L.B. Mikroskopicheskaya tekhnika [Microscopic technique]. Moscow: Sovetskaya nauka, 1957; $470 \mathrm{p}$.

20. Makarov M.S., Storozheva M.V., Konyushko O.I., Borovkova N.V., Khvatov V.B. Effect of concentration of platelet-derived growth factor on proliferative activity of human fibroblasts. Bull Exp Biol Med 2013; 155(4): 576-580, https:// doi.org/10.1007/s10517-013-2199-9. 